\title{
Isolation and characterization of native Bacillus thuringiensis strains from Saudi Arabia with enhanced larvicidal toxicity against the mosquito vector Anopheles gambiae (s.l.)
}

Talaat A. El-kersh', Ashraf M. Ahmed ${ }^{2}$, Yazeed A. Al-sheikh', Frédéric Tripet ${ }^{3 *}$, Mohamed S. Ibrahim and Ali A. M. Metwalli ${ }^{4}$

\begin{abstract}
Background: Worldwide, mosquito vectors are transmitting several etiological agents of important human diseases, including malaria, causing millions of deaths every year. In Saudi Arabia, as elsewhere, vector-control is based mostly on chemical insecticides which may be toxic and cause environmental deprivation. Here, to support the development of bio-pesticide alternatives, a study was conducted to identify native Bacillus thuringiensis (Bt) isolates with improved toxicity against the malaria vector, Anopheles gambiae (s.l.).

Methods: Sixty-eight $B t$ isolates were obtained from 300 soil and other samples collected from 16 sites across Saudi Arabia. Bt identification was based on morphological characteristics of colonies, shape of parasporal crystals and biochemical profiles. After characterization of their mosquitocidal activity, larvicidal strains were described through $16 \mathrm{~S}$ ribosomal DNA gene sequencing, cry, cyt and chi genes PCR-amplification profiles, and SDS-PAGE protein analyses.

Results: Spherical Bt crystals were predominant amongst the 68 isolates (34\%), while irregular, bi-pyramidal and sporeattached crystals were found in 32,13 and $21 \%$ of strains, respectively. $L C_{50}$ and $L C_{90}$ bioassays showed that 23/ 68 isolates were larvicidal, with distinct biochemical activity profiles compared to non-larvicidal Bt strains. Eight larvicidal strains showed larvicidal activity up to 3.4-fold higher ( $\mathrm{LC}_{50}$ range: $3.90-7.40 \mathrm{\mu g} / \mathrm{ml}$ ) than the reference Bti-H14 strain $\left(L C_{50}=13.33 \mu \mathrm{g} / \mathrm{ml}\right)$. Of these, 6 strains had cry and cyt gene profiles similar to Bti-H14 (cry4Aa, cry $4 B a, c r y 10$, cry11, cyt1Aa, cyt1Ab, cyt2Aa). The seventh strain (Bt63) displaying the highest larvicidal activity $\left(L_{50}=3.90 \mu \mathrm{g} / \mathrm{ml}\right)$ missed the cry4Aa and cyt1Ab genes and had SDS-PAGE protein profiles and spore/crystal sizes distinct from Bti-H14. The eight strain (Bt55) with $L C_{50}$ of $4.11 \mu \mathrm{g} / \mathrm{ml}$ had cry and cyt gene profiles similar to Bti-H14 but gave a chi gene PCR product size of 2027bp. No strains harbouring cry2, cry $17+27$, cry $24+40$, cry 25, cry29, cry30, or cyt2Ba were detected.

Conclusion: This study represents the first report of several Saudi indigenous Bt strains with significantly higher larvicidal efficacy against An. gambiae than the reference Bti-H14 strain. The very high toxicity of the Bt63 strain, combined with distinct cry and cyt genes and SDS-PAGE-protein profiles makes it a promising candidate for future applications in mosquito bio-control.
\end{abstract}

Keywords: Bacillus thuringiensis, Isolation, Parasporal crystals, Biochemical type, 16S rRNA, Anopheles gambiae, cry and cyt genes, SDS-PAGE

\footnotetext{
* Correspondence: f.tripet@keele.ac.uk

${ }^{3}$ Centre for Applied Entomology and Parasitology, School of Life Sciences,

Keele University, Staffordshire ST5 5BG, UK

Full list of author information is available at the end of the article
} 


\section{Background}

Mosquitoes are considered as one of the most important groups of insects that are transmitting the parasites and viruses responsible for many major infectious diseases such as malaria, filariasis, dengue, Rift Valley and yellow fevers, and Japanese encephalitis, which contribute significantly to poverty and social debility in as much as 128 tropical countries (55\% of the world's population) causing millions of deaths every year. In the absence of effective vaccines or specific anti-viral drugs for the majority of these diseases, the effective alleviation of this burden has often crucially relied on mosquito control programs [1]. The extensive and intensive use of chemical insecticides for mosquito control has been the cause of several environmental and human health concerns, including disruption of natural-biological control systems, development of mosquito resistance and undesirable effects on beneficial organisms [2]. The awareness of these problems has led developed countries to implement rigorous control on the use of harmful chemical control measures almost 10 years ago $[1,3]$; however, in the Middle East and developing countries the same measures have not always been implemented.

One of the few alternatives to chemical compounds for vector control is Bacillus thuringiensis $(B t)$. This facultative aerobic, Gram-positive, spore-forming saprophyte soil bacterium, has been successfully used as a biological insecticide over the last 6 decades and constitutes 95\% of all commercial bio-insecticides, due to its high specificity, safety and effectiveness in the control of wide spectrum of human disease vectors and agriculture-pests [4]. Spore-formation enables $B t$ to survive in harsh environments resulting in a ubiquitous distribution. $B t$ has been isolated from soil, aquatic environments including sewage, dead insects and their breeding sites, herbivore faeces, stored grains, phylloplane and forest [4]. Its persistence is thought to be comparatively shorter than that of the closely-related bacterium Lysinibacillus sphaericus. During sporulation, Bt produces one or more parasporal insecticidal proteinaceous crystals (ICPs), comprised of one or more crystal (Cry) and cytolytic (Cyt) proteins, recognized as $\delta$-endotoxins. In target insect species, ingestion of ICPs, is followed by their dissolution under prevailing alkaline $\mathrm{pH}$ in the larvae midgut and release of protoxins in the lumen that are activated by specific proteases to recognize and bind to receptors from the midgut microvilli. After binding, the toxin molecules go through oligomerization and membrane insertion that cause pore formation, and lead to eventual cell-cytolysis [5-7]. The formation of ICPs is the only phenotypic character that differentiates the two taxonomically closely related species, Bt and Bacillus cereus [8, 9], which have been proposed to be considered as a single species [10]. Hofte \& Whitely [11] were the first to describe four Cry and two Cyt $\delta$-endotoxins genes on the basis of insecticidal activity. Since genetic diversity and toxic potential of $B t$ strains has been shown to vary between countries and regions, hundreds of $B t$ strains have been isolated and characterized all over the world, with the aim to find novel active cry genes to combat the emergence of resistant insects, primarily among Lepidoptera. Nowadays, Bt Cry toxins have been classified into 73 families (Cry1 to Cry73) and six groups of Cry proteins with toxicity to various insect taxa. Cyt proteins have been classified into three families (Cyt1, Cyt2 and Cyt3) with specific toxicity against mosquitoes and blackflies [12, 13]. The latter cytotoxins are hydrophobic, show no homology to Cry proteins, and, even at low concentration, enable Cry toxins to create oligomeric pores in the cell membranes of the insect gut. Therefore, they synergize with and overcome resistance to mosquito larvicidal Cry proteins by functioning as a Cry membrane bound receptor. At high concentrations, due to their high affinity to lipids, these toxins can act as detergents by rupturing the cell membrane $[6,7,14]$. Additionally, the chitinase chi gene has been associated with enhanced mosquitocidal activity of $B t$ strains suggesting further synergism with the cyt and cry genes [7].

Bacillus thuringiensis serovar. israelensis de Barjac (Bti-H14) was the first Bt strain used as an effective biological control agent against larvae of many mosquito and blackfly species worldwide, with no adverse effects on non-target invertebrates and vertebrates. Several studies have linked the larvicidal activity of Bti to its major Cyt1Aa and Cry4Ba, Cry4Aa, Cry10, Cry11Aa proteins $[1,15,16]$. In $B t i-H 14$, these proteins are all encoded and located on a large plasmid $(128 \mathrm{~kb})$ recognized as pBtoxis [17] and differ in their mosquito toxicity [18, 19]. All four Cry-toxins, Cry4A, Cry4B, Cry10 and Cry11A are synthesized at different phases of sporulation and are added sequentially to form spherical ovoid inclusion bodies [4]. The Cry4A and Cry4B toxins have large molecular masses of (128 to $134 \mathrm{kDa}$ ), hence easily form crystals. However, Cry10 and Cry11 have lower mass of 78 and $72 \mathrm{kDa}$ (naturally truncated) and require the helper proteins, encoded by genes ( $p 19$ and $p 20)$ in the same $c r y$ operon, to facilitate their crystallization $[17,20]$. Both Cry4A and Cry4B, after dissolution in the alkali mosquito-larval midguts, are proteolytically cleaved into a C-terminal half and $\mathrm{N}$-terminal half. Only the $\mathrm{N}$-terminal halves are toxic and can be genetically manipulated to broaden such toxicity [21], whereas the C-terminal halves crystallization domains are not involved in toxicity but are necessary for crystal formation, as strategy for protection against highly intrinsic proteolytic enzymes produced concomitantly by the producer organism [20]. The larvicidal toxicity of individual Cry proteins is low and does not reach more than $5 \%$ that of the complete parasporal body, thereby highlighting their synergetic effect $[18,22]$.

Despite having been used for mosquito control for three decades, the risk of emergence of resistance to $B t i$ 
is thought to be limited due to its unique combination of Cry toxin crystals combined with Cyt toxins, which leads to complex multiple mode of actions and multiple levels of synergistic interactions. However, that risk is not completely nil and recent reports have indicated decreased susceptibilities in some field populations suggesting that future wider use of Bti might cause the emergence of mosquito-resistance [18, 19, 23].

Although the majority of natural $B t$ isolates with insecticidal activity are effective against lepidopteran larvae, strains active against dipterans are comparatively more difficult to obtain [24]. In a recent report, we succeeded in isolating native $B t$ lines from Saudi Arabia with significantly enhanced activity against Aedes caspius and slightly enhanced activity against Culex pipiens [25]. Therefore, as a continuation to our interest in the control of mosquito-borne diseases in Saudi Arabia and elsewhere $[24,25]$, this research effort was expanded to identify and characterize additional indigenous $B t$ isolates with naturally enhanced toxicity for bio-control of the malaria mosquito An. gambiae. To the best of our knowledge, this is the first report of native $B t$ strains native to Saudi Arabia with significantly enhanced larvicidal activity against an anopheline mosquito compared to the reference Bti-H14 strain [1,24] and with distinct SDS-PAGE and cry and cyt gene profiles. It is hoped that the findings of the present study may contribute to the Saudi Ministry of Health's efforts for the control of mosquito-borne diseases, and may be useful to vector control programmes in other parts of the world, where these mosquito vectors are prevailing.

\section{Methods}

\section{Field collection of environmental samples}

From October 2013 to March 2014, environmental samples $(n=300)$ were collected in sterile plastic universal tubes from 16 regions across Saudi Arabia in locations in the vicinity of mosquito breeding sites (Table 1). Samples were collected near houses, irrigated parks, gardens and farms as well as from the surrounding semi-desert areas. Collected samples were transported to the laboratory and stored at $4{ }^{\circ} \mathrm{C}$ until processed for $B t$ isolation.

\section{Bacterial isolation and culturing}

Around $1 \mathrm{~g}$ of fine grinded soil, dried leaves or animalfaeces, was added to $2.0 \mathrm{ml}$ of sterile distilled water and suspended vigorously using a Vortex Mixer; whereas, 2 $\mathrm{ml}$ of liquid samples such as, for example, sewage water were transferred to sterile tubes. Of these specimens, 2 $\mathrm{ml}$ aliquots were mixed with $2 \mathrm{ml}$ absolute ethanol to obtain $50 \%$ ethanol concentration, vortexed for $1 \mathrm{~min}$ and then incubated at $30{ }^{\circ} \mathrm{C}$ for 45 min with regular shaking. After ethanol treatment, 1/10 serial dilutions in sterile distilled water were carried out $\left(1 \times 10^{-1}-10^{-3}\right)$ and spread on synthetic nutrient agar (SNA) medium supplemented with $0.2 \%$ yeast extract (Sisco research laboratories, Mumbai, India) and $0.005 \%$ of manganese chloride $\left(\mathrm{MnCl}_{2}\right)$, and incubated at $30{ }^{\circ} \mathrm{C}$ for 2 to 3 days depending on spore maturation $[24,25]$.

\section{Bt colony morphology analysis}

$B t$-like colonies, white, large, nearly circular with fine irregular margins and may be glossy, less glossy or rough were selected. To exclude closely related $B$. cereus and other spore-forming bacilli, the suspected colonies were then examined under phase contrast microscopy for the presence of parasporal crystals. For comparison, the $B t$ index was calculated for each positive sample as number of identified $B t$ colonies divided by the total number of spore-forming bacilli colonies [24, 25].

\section{Biochemical activity typing}

In addition to spore formation, positive Gram staining, and parasporal crystal detection, further phenotypic characterization and identity confirmation of recovered $68 \mathrm{Bt}$ isolates were accomplished on the basis of esculin and lecithinase hydrolysis, hemolytic and motility activities, and carbohydrate utilization (API $50 \mathrm{CH}$ system) as previously described [24]. The resulting API data analysis confirmed the identity (95-99\%) of native Bt-like isolates as Bacillus thuringiensis strains.

\section{Bt crystal morphology analysis}

Next, confirmed $B t$ colonies were suspended in sterile water, wet mounted, and then examined under Phase Contrast Microscope at a $100 \times$ magnification for presence of parasporal crystals. They were then purified by sub-culturing on SNA medium for $48 \mathrm{~h}$ and stored at $-20{ }^{\circ} \mathrm{C}$ as stock culture in sterile liquid nutrient broth containing 50\% glycerol. Subsequent morphometric measurements of spore or crystal sizes were performed with Scanning Electron Microscopy (SEM) as previously described [24].

\section{Mosquito maintenance}

Anopheles gambiae (s.l.) mosquitoes were maintained at the Centre for Applied Entomology and Parasitology at Keele University, United Kingdom under standardized conditions as detailed in [26]. Adult female mosquitoes were fed on horse blood using an artificial feeder (Hemotek membrane feeding system, Discovery workshops, UK) set at $37^{\circ} \mathrm{C}$ [26]. Eggs were laid 2 days after blood-feeding and hatched within 2 days. About 200 hatched first larval instars were distributed into $1 \mathrm{~L}$ of de-ionized water in plastic trays $(34 \times 24 \mathrm{~cm}$ each). One drop of Liquifry (Interpet Ltd, Dorking, UK) was added to each dish for 2 days then, were fed on ground TetraMin flake food (Tetra Werke, Melle, Germany) until pupation. Pupae were 
Table 1 Geographical distribution of sampling sites, total number of samples $(N)$, and number of Bt-positive, Bt index, and number of larvicidal isolates

\begin{tabular}{|c|c|c|c|c|c|}
\hline City-region & Geographic location (GPS) & $N$ & Bt-positive & Bt index ${ }^{a}$ & Larvicidal \\
\hline Al Madinah & $24^{\circ} 28^{\prime} 0^{\prime \prime} \mathrm{N}, 39^{\circ} 36^{\prime} \mathrm{O}^{\prime \prime} \mathrm{E}$ & 52 & 18 & 0.43 & 12 \\
\hline Yanbu & $24^{\circ} 5^{\prime} \mathrm{O}^{\prime \prime} \mathrm{N}, 38^{\circ} \mathrm{O}^{\prime} \mathrm{O}^{\prime \prime} \mathrm{E}$ & 32 & 5 & 0.12 & 2 \\
\hline Makkah & $21^{\circ} 30^{\prime} 0^{\prime \prime} \mathrm{N}, 41^{\circ} 0^{\prime} 0^{\prime \prime} \mathrm{E}$ & 22 & 7 & 0.24 & 2 \\
\hline Taif & $21^{\circ} 16^{\prime} 0^{\prime \prime} \mathrm{N}, 40^{\circ} 25^{\prime} 0^{\prime \prime} \mathrm{E}$ & 14 & 5 & 0.66 & 0 \\
\hline Jeddah & $21^{\circ} 50^{\prime} 0^{\prime \prime} \mathrm{N}, 39^{\circ} 10^{\prime} \mathrm{O}^{\prime \prime} \mathrm{W}$ & 2 & 0 & - & 0 \\
\hline Qassim & $25^{\circ} 49^{\prime} 20^{\prime \prime} \mathrm{N}, 42^{\circ} 50^{\prime} 7 " \mathrm{E}$ & 39 & 4 & 0.23 & 1 \\
\hline Alehssa & $25^{\circ} 25^{\prime} 46^{\prime \prime} \mathrm{N}, 49^{\circ} 37^{\prime} 19^{\prime \prime} \mathrm{E}$ & 9 & 2 & 0.67 & 0 \\
\hline Dammam & 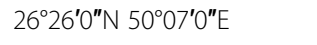 & 7 & 0 & - & 0 \\
\hline Qatif & $26^{\circ} 56^{\prime} 0^{\prime \prime} \mathrm{N}, 50^{\circ} 1^{\prime} \mathrm{O}^{\prime \prime} \mathrm{E}$ & 6 & 0 & - & 0 \\
\hline Hafr al Batin & $28^{\circ} 26^{\prime} 3^{\prime \prime} \mathrm{N}, 45^{\circ} 57^{\prime} 49^{\prime \prime} \mathrm{E}$ & 22 & 4 & 0.21 & 1 \\
\hline Riyadh region & $24^{\circ} 38^{\prime} 0^{\prime \prime} \mathrm{N}, 46^{\circ} 43^{\prime} \mathrm{O}^{\prime \prime} \mathrm{E}$ & 37 & 9 & 0.22 & 1 \\
\hline Asser & $19^{\circ} 0^{\prime} \mathrm{O}^{\prime \prime} \mathrm{N}, 43^{\circ} \mathrm{O}^{\prime} \mathrm{O}^{\prime \prime} \mathrm{E}$ & 13 & 4 & 0.15 & 2 \\
\hline Khamis Musheet & $18^{\circ} 18^{\prime} 0^{\prime \prime} \mathrm{N}, 42^{\circ} 44^{\prime} \mathrm{O}^{\prime \prime} \mathrm{E}$ & 8 & 1 & 0.68 & 0 \\
\hline Abhaa & $18^{\circ} 13^{\prime} 24^{\prime \prime} \mathrm{N}, 42^{\circ} 30^{\prime} 26^{\prime \prime} \mathrm{E}$ & 10 & 3 & 0.13 & 0 \\
\hline Jezan & $16^{\circ} 53^{\prime} 211^{\prime \prime} \mathrm{N}, 42^{\circ} 33^{\prime} 40^{\prime \prime} \mathrm{E}$ & 25 & 5 & 0.70 & 2 \\
\hline Najran & $17^{\circ} 29^{\prime} 30^{\prime \prime} \mathrm{N}, 44^{\circ} 7^{\prime} 56^{\prime \prime} \mathrm{E}$ & 2 & 1 & 0.12 & 0 \\
\hline Total & & 300 & 68 & 0.35 & 23 \\
\hline
\end{tabular}

${ }^{\mathrm{a}}$ The number of identified $B t$ colonies divided by the total number of spore-forming colonies

separated daily, placed in polystyrene pots containing distilled water, and kept in their rearing cages until adult emergence [26].

\section{Bt spores/crystals mixture and preliminary mosquito- bioassay}

The spores and crystals mixture of each native $B t$ isolates cultured on SNA plates $(72 \mathrm{~h}$ ) were scrapped into $10 \mathrm{ml}$ of sterile water, to give an average count of $10^{9}$ colony forming units (CFU) per $\mathrm{ml}$. At the beginning a high spores/crystals mixture was used in parallel with that of the $B t$ serovar israelensis de Barjac reference strain (BtiH14) [24] in preliminary screening of larvicidal activity.

For preliminary bioassays, groups of 20 third-instar larvae were transferred into $30 \mathrm{ml}$ plastic cups containing $20 \mathrm{ml}$ of chlorine-free tap water using a Pasteur pipette. To detect even low larvicidal activity, the crude $B t$ spores/crystals mixture $\left(\sim 1 \times 10^{8-9} \mathrm{CFU} / \mathrm{ml}\right)$ was then added and larval mortality of tested isolate was scored $24 \mathrm{~h}$ after incubation at $22 \pm 1{ }^{\circ} \mathrm{C}$ and compared to that of the negative control. Out of the tested native $B t$ isolates, those that exhibiting significant mosquitolarvicidal activity (100\% mortality), were selected for further bioassay assessment and spore counts.

\section{S rRNA gene analysis}

Fresh colonies of a sample of 23 isolates (19 larvicidal, 4 non-larvicidal), as well as $B$. cereus (ATCC1177) and the reference $B t i$-H14 strains, were picked up with a sterilized toothpick, and suspended in $0.5 \mathrm{ml}$ of sterilized saline in a $1.5 \mathrm{ml}$ centrifuge tube, centrifuged at $3,500 \times g$ for $10 \mathrm{~min}$. After removal of supernatant, the pellet was suspended in $0.5 \mathrm{ml}$ of InstaGene Matrix (Bio-Rad, USA), incubated at $56{ }^{\circ} \mathrm{C}$ for $30 \mathrm{~min}$ and then heated at $100{ }^{\circ} \mathrm{C}$ for $10 \mathrm{~min}$. After heating, supernatant DNA was used for PCR $16 \mathrm{~S}$ rRNA gene analysis. PCR amplification of $16 \mathrm{~S}$ rRNA gene from tested $B t$ isolates was performed using the universal primers: forward (518F): 5'-CCA GCA GCC GCG GTA ATA CG-3'; reverse (800R): 5'-TAC CAG GGT ATC TAA TCC-3', essentially as previously described [24]. The purified PCR products of approximately $1,400 \mathrm{bp}$ were sequenced using Big Dye terminator cycle sequencing (Macrogen, Seoul, Korea) with 2 primers (27F): 5'-AGA GTT TGA TCM TGG CTC AG-3' and (1492R): 5'-TAC GGY TAC CTT GTT ACG ACT T-3'). Sequences were searched against the NCBI Nucleotide database (www.ncbi.nlm.nih.gov) using the BLAST tool with a similarity cut-off of $99.5 \%$ to identify the bacterium based on sequence homology. Using the programme Clustal-X [27], a multiple alignment was build using the 16S RNA gene sequences of larvicidal and non-lethal $B t$ isolates, the sequences from the colony-grown Bti-H14 reference and $B$. cereus strains, and sequences from the genomes of $B$. pumilus, and B. megatorium, used as Gram-positive bacteria outgroups (Additional file 1: Table S1) [24]. The software Seaview4 [28] was used to build a boot-strapped neighbour-joining tree in order to establish the relative degree of genetic similarity between the sequences. 


\section{Detailed mosquito larvicidal bioassays}

To avoid possible discrepancy during the preparation of spores/crystals mixture for quantitative determination of $\mathrm{LC}_{50}$ and $\mathrm{LC}_{95}$ mortality bioassay, the spores/crystals mixtures of the active 23 native $B t$ isolates were prepared from fermentation growth on Nutrient Yeast Extract Salt Medium, NYSM (containing per litter: $5 \mathrm{~g}$ glucose, $5 \mathrm{~g}$ peptone, $5 \mathrm{~g} \mathrm{NaCl} ; 3 \mathrm{~g}$ beef extract, $0.5 \mathrm{~g}$ yeast extract, $0.02 \mathrm{~g}$ magnesium chloride, $1 \mathrm{mg}$ manganese chloride and $0.01 \mathrm{~g}$ calcium chloride, $\mathrm{pH}$ 7.2) and prepared as dried powder in adequate amount using the lactose acetone coprecipitation procedure [29]. The resulting white fine toxin powders were stored at $4{ }^{\circ} \mathrm{C}$.

For detailed characterization of mosquito larvicidal activity, the $\mathrm{LC}_{50}$ and $\mathrm{LC}_{95}, 24 \mathrm{~h}$ post-treatment of the native larvicidal $B t$ isolates and $B t i-\mathrm{H} 14$ reference strain were established using bioassays conducted on thirdinstar larvae of An. gambiae. For each bioassay, five concentrations from each active toxin powder were used as recommended by WHO [35] with modifications. Briefly, 20 third-instar larvae were placed in each well of a sterile standard 12-wells tissue culture test plate (Nunclone Delta Surface, Thermo-Fischer Scientific, Denmark) with $2 \mathrm{ml}$ de-ionized water mixed with either $10 \mu \mathrm{l}$ of each dilution of toxin powder solution [36] or $10 \mu \mathrm{l}$ de-ionized water for the negative control larval group. Another set of larvae groups were treated with the reference Bti-H14 strain as positive control for comparison. Meanwhile, samples from each of the same serial dilutions of $B t$ toxin were cultured on SNA medium to estimate spore counts by counting the number of $\mathrm{CFU} / \mu \mathrm{g}$. Each bioassay was run for $24 \mathrm{~h}$, during which larvae were fed to avoid mortality caused by starvation. After $24 \mathrm{~h}$, the percentage of larval mortality was calculated for each concentration using Abbott's formula [37]. Bioassays comprising one replicate of each concentration were replicated five times for every strain tested.

\section{DNA extraction for PCR detection of cry and cyt genes contents}

A single fresh colony of each larvicidal $B t$ isolates and the reference Bti-H14 [24], were suspended into $100 \mu \mathrm{l}$ sterile distilled water in an Eppendorf tube and boiled in waterbath for $10 \mathrm{~min}$. Bt suspensions were then immediately cool-shocked at $-20{ }^{\circ} \mathrm{C}$. This heat-shock process was repeated three times to allow complete cell-lysis before centrifugation (Multifuge 3SR+ Centrifuge, Thermo Scientific Electron Corporation, Germany) at 3,500 $g$ for $10 \mathrm{~min}$ at $4{ }^{\circ} \mathrm{C}$. The resultant supernatant containing the crude DNA was used for PCR amplification, using the Hot Start Taq DNA polymerase and Master Mix Kit (QIAGEN Technologies, Germany) as described in Bukhari \& Shakoori [30].

Each native $B t$ isolates and the reference Bti-H14 strains were PCR-screened using five universal primers designed from conservative regions of the cry2, cry4, cry 11 , cyt1 and cyt2 genes as previously described [31-33] as well as 13 primers specific to highly variable regions of the cry $4 a, c r y 4 b a, c r y 10, c y t 1 A a, c y t 1 A b, c y t 2 A a, c y t 2 B a$, cry $17+27$, cry $24+40$, cry 25 , cry 29 , cry30 (Additional file 2: Table S2). The chi gene, known for its chitinase activity that may increase insecticidal toxicity [7], was also examined using a set of specific primers (Additional file 2: Table S2). Oligonucleotide primers were synthesized in a DNA synthesizer (Applied Biosystems, Foster City, CA, USA) using the manufacturer's instructions. PCR amplifications were performed as previously described [25] and the resulting amplicons were visualized by running the PCR products $(15 \mu \mathrm{l})$ on $2 \%$ agarose electrophoretic gels as described in Mahalakshmi et al. [34].

\section{SDS-PAGE analysis}

The SDS-PAGE protein profiles of $B t$ isolates and the references $B t$-H14 were established as previously described in Bukhari \& Shakoori [30] and El-Kersh et al. [25].

\section{Data analysis}

All statistical analyses for calculating $\mathrm{LC}_{50}, \mathrm{LC}_{95}$, slopes, and standard error values of each treatment were undertaken according to Finney [38]. Any two relevant treatments were considered as not significantly different in their toxicity if the $95 \%$ confidence intervals of their $\mathrm{LC}_{50}$ overlapped [39].

\section{Results}

\section{Geographical distribution of positive $B t$ isolates}

A total of 300 samples were collected from 16 different regions of the Kingdom of Saudi Arabia (Table 1) and screened for $B t$ presence. A total of 68 native $B t$ isolates were recovered from 55 samples of soil, dried plant leaves, dried animal dung, sewage water, irrigation water, stagnant rain water, insects, snails and fish guts. Another 245 samples failed to yield any $B t$ isolates. Of the $55 \mathrm{Bt}$-positive samples, some contained several $B t$ strains which diverse colonial morphology and parasporal crystal shapes, whereas other samples only a single $B t$ strain. The highest diversity of $B t$ isolates were recovered from Madinah, Jezan, Asser and Yombu regions. Other city/regions yielded positive $B t$ isolates but with comparatively lower diversity regardless of respective $B t$ indices (Table 1 ).

\section{Morphological characterization of Bt colonies}

Wet mount phase-contrast microscopy allowed the identification of 68 native potential $B t$ isolates with characteristic $B t$-like colonial morphology and presence of parasporal crystals. Of these, only 23 exhibited larvicidal activity in preliminary bioassays. The colony growth of these strains on SNA medium bore strong similarities with those of the reference Bti-H14, showing white 
colour, large size, nearly circular shape with fine irregular margins and usually glossy. In contrast, the 45 nonlarvicidal $B t$ isolates showed much greater morphological variation. However, all native $B t$ isolates shared many morphological characteristics in cell chains arrangement, ellipsoidal shape of spores, and non-swollen sporangia. As expected, both the 23 larvicidal and 45 non-larvicidal native $B t$ isolates exhibited remarkable variation in the position and shape of crystals within sporangia. Based on this variation, the 68 native $B t$ isolates were broadly classified into four classes: (i) small and/or large spherical (34\%); (ii) bi-pyramidal (13\%); (iii) irregular: cubic, spherical, merged triangular, or conicalbudding (32\%); and (iv) spherical, triangular, cubic or bipyramidal attached to spores (21\%).

\section{Biochemical typing}

In a previous study, biochemical typing of 3,639 Bt isolates [40] showed that urease producers were strongly associated with the production of lepidopteran-toxic bipyramidal crystals, whereas amorphous and/or irregular crystal formers with dipteran toxicity, were mostly associated with either general low metabolic activity, positive for acid production from starch and lecithinase and/or esculine hydrolysis. Here, the 68 native $B t$ isolates were negative for $\mathrm{H}_{2} \mathrm{~S}$, urease, and indole production and rarely positive for ONPG or acid production from rhamnose (Table 2). $B t$ isolates showed great variation in their ability to utilize citrate (25\%), to reduce nitrate $(62 \%)$ and produce acid from starch (75\%), sucrose (65\%), mannitol (45\%), inositol (44\%) and sorbitol (39\%). Most isolates were positive for gelatinase liquification, esculin hydrolysis and lecithinase production, hemolytic (94\%) and motile (90\%) activities. However, all 23 larvicidal $B t$ isolates (100\%) exhibited active motility and hemolytic activity as well as lecithinase and esculin hydrolysis, but were negative for salicin.

\section{Larvicidal bioassays}

Preliminary screening of larvicidal bioassays revealed that only 23/68 (34\%) of $B t$ isolates showed promising mosquito larvicidal activities and these were further characterized with regard to their toxicity. The results of detailed $\mathrm{LC}_{50}$ and $\mathrm{LC}_{95}$ bioassays and spore count (CFU per $\mu \mathrm{g}$ powder) confirmed that all 23 native $B t$ isolates identified as larvicidal in preliminary test had various level of efficacy against An. gambiae third-instar larvae (Table 4). The $\mathrm{LC}_{50}$ of most $(n=15)$ of the tested $23 \mathrm{Bt}$ isolates did not significantly differ than that of the reference Bti-H14 $\left(\mathrm{LC}_{50}: 13.33 \mu \mathrm{g} / \mathrm{ml}\right.$ and spore count of 4.5 $\pm 0.3 \times 10^{5} \mathrm{CFU} / \mu \mathrm{g}$ powder). Notably, as much as eight native $B t$ strains exhibited significantly higher larvicidal activity against An. gambiae than that of Bti-H14 reference strain. These isolates coded $B t$ No. $63,55,10,68$, $58,42,67$ and 57 , showed $\mathrm{LC}_{50}$ of $3.90,4.11,4.96,5.16$, $5.73,5.90,6.90$ and $7.40 \mu \mathrm{g} / \mathrm{ml}$, respectively (Table 3). Their respective $\mathrm{LC}_{95}$, higher Probit regression slope values and their $\mathrm{CFU}$-spore counts per $\mu \mathrm{g}$ of powder similar or lower than the reference Bti-H14 strain confirmed their higher toxicity.

\section{S rRNA gene analysis}

A total of 19 larvicidal and 4 non-larvicidal native $B t$ isolates with varying biochemical profiles were used for 16S rRNA gene analysis, along with the reference strain Bti-H14 and B. cereus (ATCC1177) strain. Amplified target bands $(\sim 1,550 \mathrm{bp})$, were detected by agarose gel electrophoresis, for all tested Bt strains and B. cereus [24] before being sequenced. In addition, 16S rRNA genome reference sequences from Lysinibacillus sphaericus, $\mathrm{Ba}$ cillus pumilus and B. megatorium were used as outgroups in a neighbour-joining analysis.

Initial results of the BLAST analysis of the nucleotide sequence proved that the 24 tested isolates, including the colony grown Bti-H14 and B. cereus strains, were all highly homologous to the B. thuringiensis genome $(99.5 \%$ homology in all cases). Furthermore, the neighbour-joining analysis confirmed that all new $B t$ isolates, including larvicidal and non-larvicidal ones, belonged to the previously described B. cereus and B. thuringiensis clade also referred to as B. cereus (s.l.) complex [41] and shared a high degree of genetic similarity (Fig. 1). This included several isolates significantly more toxic than the reference Bti-H14

Table 2 Biochemical profiles of the 68 native Bt isolates from Saudi Arabia using the API 50CH system. The percentage of isolates actively metabolizing different substrates is indicated

\begin{tabular}{|c|c|c|c|c|}
\hline 100\% positive & $>90 \%$ positive & 10-90\% positive & $<10 \%$ positive & $100 \%$ negative \\
\hline L-Tryptophane & L-Arginine (99) & Citrate (25) & Rhamnose (4) & L-Lysine \\
\hline Gelatin & Glucose (95) & Sodium pyruvate (69) & ONPG (1) & L-Ornithine \\
\hline \multirow[t]{6}{*}{ Esculin } & & Mannitol (45) & & Sodium thiosulfate \\
\hline & & Inositol (44) & & Urea \\
\hline & & Sucrose (65) & & Indole \\
\hline & & Sorbitol (39) & & Salicin \\
\hline & & Starch (75) & & Melibiose \\
\hline & & Nitrate (62) & & Arabinose \\
\hline
\end{tabular}


Table 3 Toxicity of 23 Bt isolates and the Bti-H14 reference strain against third-instar larval stage of An. gambiae 24 h post-treatment

\begin{tabular}{|c|c|c|c|c|c|}
\hline Bt-code & Region & $\mathrm{LC}_{50}(\mu \mathrm{g} / \mathrm{ml})^{\mathrm{a}}$ & $\mathrm{LC}_{95}(\mu \mathrm{g} / \mathrm{ml})^{a}$ & Slope \pm SE & $\mathrm{CFU} / \mu \mathrm{g} \times 10^{5 \mathrm{~b}}$ \\
\hline Bti-H14 & - & $13.3(11.2-15.9)$ & $63.7(40.4-102.3)$ & $2.4 \pm 0.07$ & $4.5 \pm 0.3$ \\
\hline Bt05 & Kharj & $13.4(11.07-16.5)$ & 78.5 (46.0-137.0) & $2.15 \pm 0.06$ & $1.0 \pm 0.1$ \\
\hline Bt07 & Asseer & $15.0(12.2-18.8)$ & $90.4(50.5-166.0)$ & $2.12 \pm 0.07$ & $1.0 \pm 0.2$ \\
\hline Bt10 & Qassim & $5.0(4.4-5.6)^{*}$ & $18.6(14.6-23.8)$ & $2.90 \pm 0.06$ & $1.2 \pm 0.3$ \\
\hline Bt11 & Yanbu & $12.3(10.2-14.8)^{*}$ & $72.6(43.5-124.3)$ & $2.10 \pm 0.06$ & $0.65 \pm 0.3$ \\
\hline Bt12 & Yanbu & $9.5(8.3-10.9)^{*}$ & $41.6(29.4-59.6)$ & $2.60 \pm 0.06$ & $0.53 \pm 0.4$ \\
\hline Bt16 & Asser & $13.0(10.6-16.0)$ & $84.2(47.8-152.6)$ & $2.02 \pm 0.06$ & $0.92 \pm 0.3$ \\
\hline$B+17$ & Hafr-elbaten & $22.0(18.2-26.7)$ & $128.5(76.4-219.7)$ & $2.14 \pm 0.06$ & $8.1 \pm 0.4$ \\
\hline Bt26 & Madinah & $12.9(9.9-16.9)$ & $149.7(64.7-367.2)$ & $1.54 \pm 0.05$ & $4.1 \pm 0.7$ \\
\hline Bt27 & Madinah & $7.1(6.1-8.2)^{*}$ & $40.1(27.3-60.2)$ & $2.20 \pm 0.05$ & $5.9 \pm 0.4$ \\
\hline Bt28 & Makkah & $8.6(7.7-9.6)^{*}$ & $27.5(22.4-33.9)$ & $3.30 \pm 0.07$ & $6.2 \pm 0.3$ \\
\hline Bt29 & Madinah & $14.4(12.4-16.7)$ & $49.4(34.1-72.3)$ & $3.10 \pm 0.12$ & $0.52 \pm 0.1$ \\
\hline Bt42 & Jezan & $5.9(5.2-6.8)^{*}$ & $24.3(18.9-31.3)$ & $2.70 \pm 0.07$ & $0.93 \pm 0.3$ \\
\hline Bt44 & Jezan & $16.1(13.7-18.9)$ & $91.9(59.3-144.2)$ & $2.20 \pm 0.05$ & $0.63 \pm 0.4$ \\
\hline Bt53 & Madinah & $13.8(11.7-16.4)$ & $101.7(61.3-171.9)$ & $1.90 \pm 0.05$ & $1.3 \pm 0.4$ \\
\hline Bt55 & Madinah & $4.1(3.6-4.6)^{*}$ & $14.4(11.6-18.1)$ & $3.02 \pm 0.07$ & $1.95 \pm 0.3$ \\
\hline$B+56$ & Madinah & $11.7(10.2-13.5)^{*}$ & $43.8(31.2-62.2)$ & $2.90 \pm 0.08$ & $0.15 \pm 0.3$ \\
\hline$B+57$ & Madinah & $7.4(6.5-8.25)^{*}$ & $26.1(20.9-32.9)$ & $2.98 \pm 0.07$ & $1.27 \pm 0.3$ \\
\hline Bt58 & Madinah & $5.7(5.1-6.5)^{*}$ & $24.6(18.6-32.9)$ & $2.60 \pm 0.05$ & $1.24 \pm 0.2$ \\
\hline Bt59 & Madinah & $10.3(8.5-12.6)^{*}$ & $84.9(46.3-161.6)$ & $1.80 \pm 0.05$ & $1.28 \pm 0.2$ \\
\hline Bt60 & Madinah & $14.7(12.5-17.5)$ & $58.2(38.1-89.9)$ & $2.75 \pm 0.10$ & $0.13 \pm 0.1$ \\
\hline Bt63 & Makkah & $3.9(3.4-4.4)^{*}$ & $15.7(12.3-20.3)$ & $2.70 \pm 0.06$ & $0.7 \pm 0.2$ \\
\hline Bt67 & Madinah & $6.9(5.9-8.2)^{*}$ & $50.6(31.5-83.4)$ & $1.90 \pm 0.05$ & $0.6 \pm 0.1$ \\
\hline Bt68 & Madinah & $5.2(4.5-5.8)^{*}$ & $21.6(16.6-28.5)$ & $2.64 \pm 0.06$ & $1.05 \pm 0.3$ \\
\hline
\end{tabular}

${ }^{*}$ Asterisks indicate significant differences compared to the reference Bti-H14

${ }^{\mathrm{a}} \mathrm{LC}_{50}$ and $\mathrm{LC} 95$, Lethal concentration that kills 50 and $95 \%$ of larval population $(n=20)$, respectively (calculated by Probit analysis and reported with $95 \%$ confidence intervals)

${ }^{\mathrm{b}} \mathrm{CFU}$, colony forming unit (mean \pm standard error). Each bioassay comprised five concentrations, one replicate for each concentration, and were repeated five times $(n=5)$

reference. The highly toxic Bt63 isolate was also closely related to Bti-H14. In summary, all tested strains, were found to be relatively homogenous and to share a high degree of phylogenetic relatedness.

\section{cry, cyt and chi gene PCR-profiling}

Each of these 23 isolates and the Bti-H14 strain were tested for positive amplification of the cry and cyt and chi genes specific to Diptera using a battery of previously-described universal and specific primers [25, 31-34] (Additional file 2: Table S2). All examined isolates yielded amplicons of the predicted size for cry4, cry11, cyt1 and cyt2 (Fig. 2a-f). Similarly, and except for the highly mosquitocidal Bt63 which showed no amplification for $\operatorname{cry} 4 A a$, most isolates yielded the expected amplicons for cry $4 A a$, cry $4 B a$, cry10, cyt1Aa and cyt2Aa. This was also true for the reference $B t i-\mathrm{H} 14$ strain. $B t-63$ as well as the isolates $B t 16, B t 56, B t 60$ and $B t 67$ did not yield bands for the cyt $1 \mathrm{Ab}$ gene (Fig. $2 \mathrm{~g}$ ). None of the isolates showed amplification for the cyt $2 B a, c r y 2$, cry $17+27$, cry $24+$ 40 , cry 25 , cry 29 and cry30 genes (data not shown). Only two native $B t$ isolates $(B t-12$ and $B t-55)$ showed amplification of chi gene PCR products at the expected size $(\sim 2,027 \mathrm{bp})$ (Fig. $2 \mathrm{~g})$. The isolate $(B t-55)$ had the same cry and cyt genes profile as Bti-H14 but had significantly higher larvicidal activity against Anopheles, supporting the idea of a Chitinase-induced additive or synergistic larvicidal effect (Table 4). However, several native Bt isolates (e.g. Bt17, Bt29, Bt44) with significantly lower larvicidal activity than the Bti-H14 reference had identical cry and cyt genes profile to it and this was also true for several of the strains with significantly higher mosquitocidal activity (Table 4). With the exception of, Bt63, Bt55 and Bt67 strains, the remaining four strains showed cry and cyt gene amplification profiles similar to Bti-H14. Thus, whilst PCR-amplification profiles provided some 


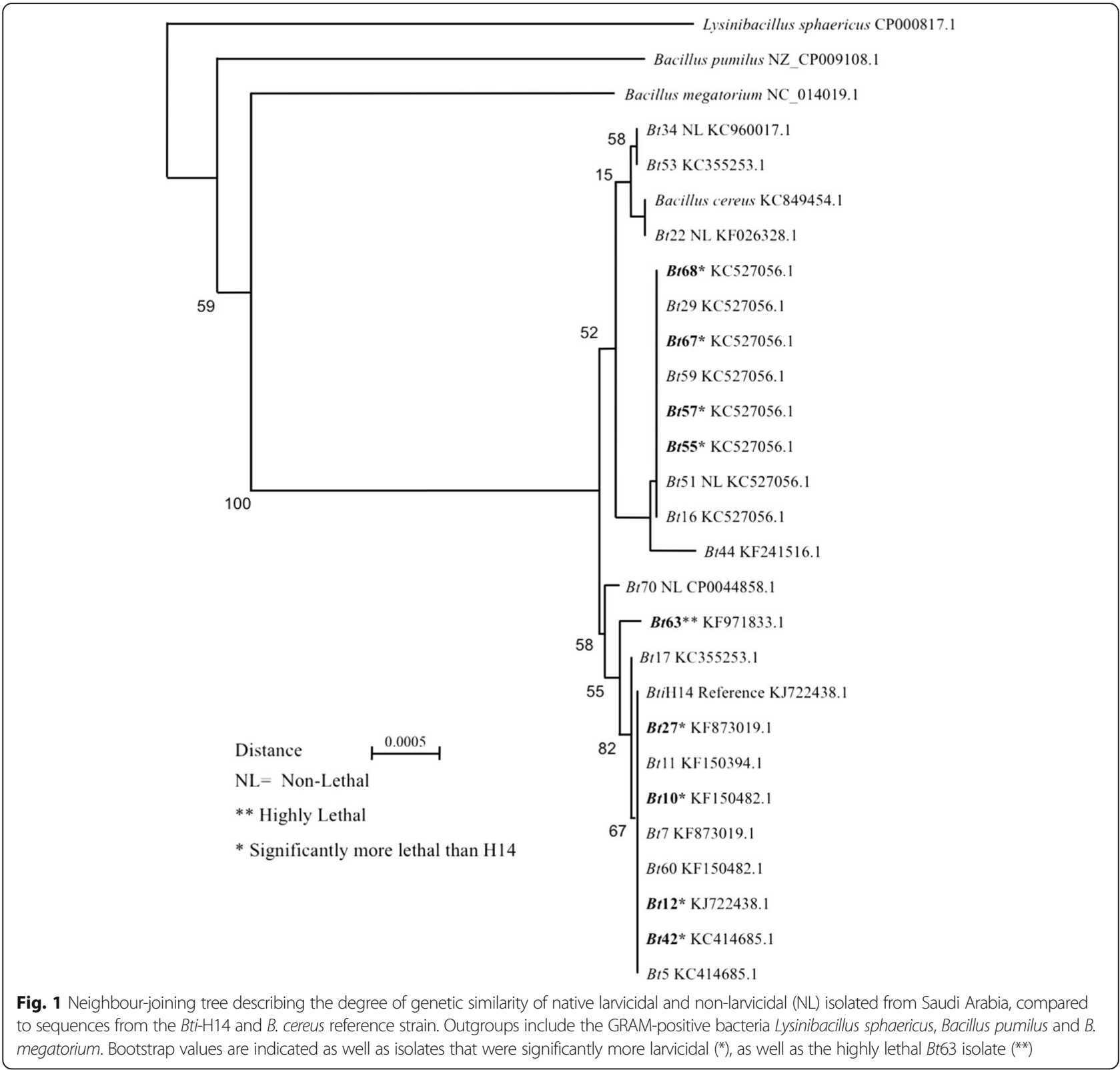

information about possible genetic variation in the determinants of mosquitocidal activity, the large remaining variation in bioactivity combined with possible occurrence of null-alleles called for more powerful bio-molecular approaches.

\section{SDS-PAGE analysis}

Further comparisons between the highly mosquitocidal Bt63 strain, the known reference Bti-H14 and other native mosquitocidal isolates were performed through SDS-PAGE analysis of the protein profiles of sporulated cultures (Fig. 3). Three experimental approaches were conducted: (i) direct spores/crystals suspension (collected $72 \mathrm{~h}$ after sporulation), SDS-solubilisation, centrifugation, immediately followed by
SDS-PAGE analysis [42] (Fig. 3a); (ii) previously-collected spores/crystals protein solubilisation $(\mathrm{pH} 10.5-11)$, centrifugation to remove spores, $\mathrm{pH}$-neutralization, protein determination, then SDS-PAGE analysis (Fig. 3b), and (iii) SDS-PAGE analysis with trypsin-activated solubilized protein $(1 \mu \mathrm{g}$ trypsin/20 $\mu \mathrm{g}$ protein) as mentioned above but with silver staining (Fig. 3c). Overall, the native $B t$ isolates showed similar protein-pattern as that of Bti-H14 in all three experimental conditions. However, the protein profile of Bt63 was strikingly different from that shown for the reference strain Bti-H14 here and in a previous report [42]. Whilst Bt63 shared several bands ( $\geq 75 \%$ ) with Bti-H14, it had two distinct additional bands with molecular masses of 68 to 74 and $99 \mathrm{kDa}$, and was missing one band of around 

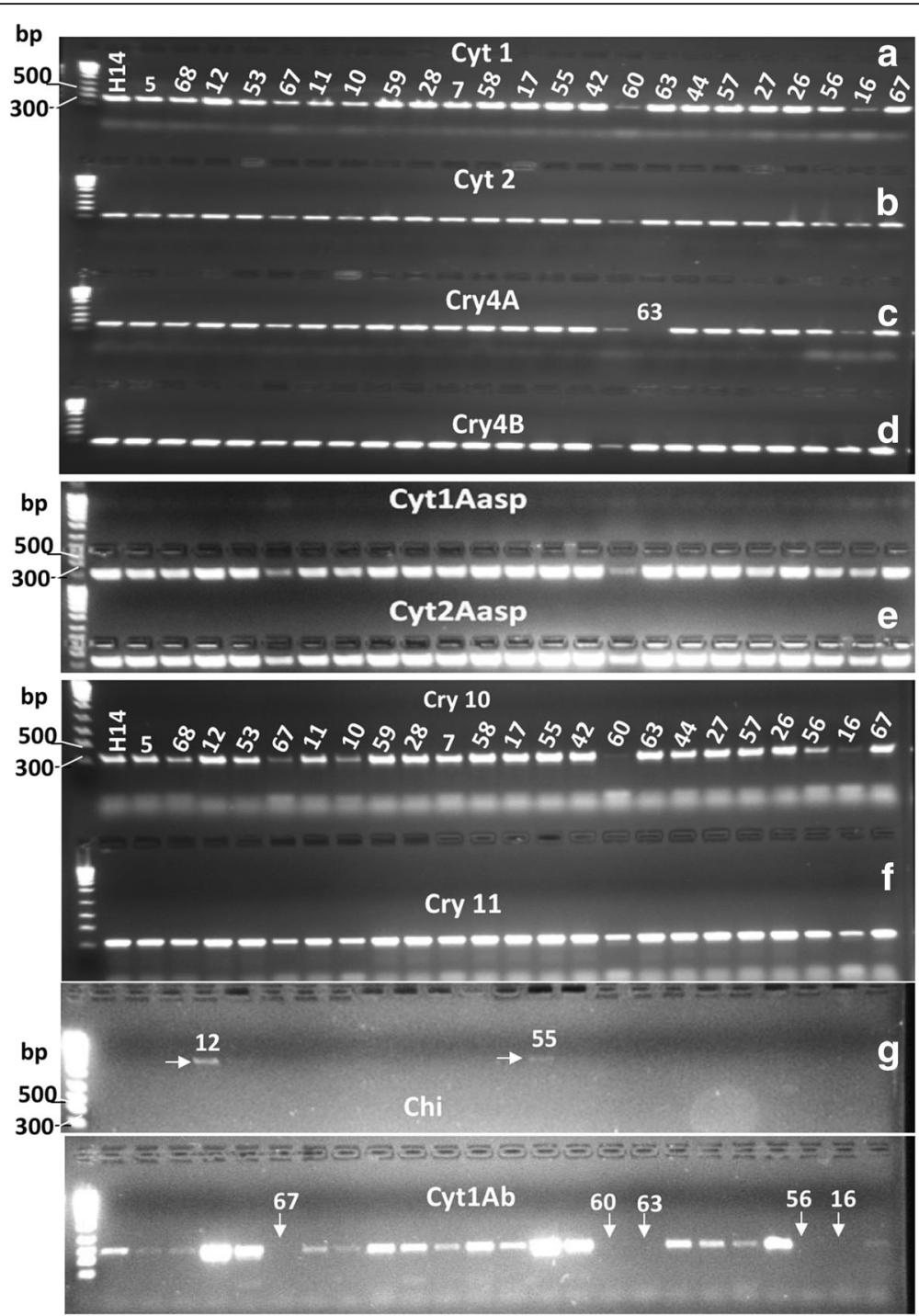

Fig. 2 Photographs of agarose electrophoresis gels (2\%) for PCR-profiling with a panel of Cny, Cyt and Chi gene primers. From left to right and for all panels: Lane 1: 100 bp ladder; Lane 2: reference Bti-H14; Lanes 3-25: the 23 native Bt strains indicated by their corresponding identification numbers (see Table 3). In $\mathbf{a}, \mathbf{b}, \mathbf{d}-\mathbf{f}$, all 23 native Bt strains including Bti-H14 displayed positive amplification of Cyt1, Cyt2, Cry4B, Cry10, Cry11, Cyt1 Aa and Cyt2Aa. In c, all strains were positive for Cry4A except Bt63. In $\mathbf{g}$, all Bt strains were PCR negative for Chi gene except Bt-12 and 55; whereas all Bt strains were PCR positive for Cyt1Ab gene, except the native isolates coded $67,60,63,56$ and 16

$28 \mathrm{kDa}$, the expected size for the missing Cyt1Ab, suggesting that it is a natural variant of Bti-H14 (Fig. 3c).

\section{Further characterisation of the toxic Bt-63 strain}

Biochemical typing of both strains using the in API $50 \mathrm{CH}$ System revealed that the only notable difference between $B t 63$ and the reference Bti-H14 was that the former produces acid from sucrose whereas the $B t-\mathrm{H} 14$ does not (Fig. 4a-b).

Detailed morphometric comparisons of largest spherical to ovoid crystals and spores (5 field readings for each) collected from growth on NYSM liquid medium from the highly larvicidal Bt63 and Bti-H14 reference were conducted by Scanning Electron Microscopy (SEM) [24] (Fig. 4c-d). The average size of spores (Length $\pm \mathrm{SD} \times$ Width \pm SD) tended to be larger in Bti-H14 $(1.75 \pm 0.12 \times$ $0.964 \pm 0.049 \mu \mathrm{m})$ than in $B t 63(1.60 \pm 0.15 \times 0.931 \pm 0.076$ $\mu \mathrm{m})$. Comparing the smallest crystals ( 5 field readings for each) found in both strains showed that these reached a smaller size in Bti-H14 $(0.618 \pm 0.043 \times 0.510 \pm 0.096 \mu \mathrm{m})$ than in Bt63 $(0.702 \pm 0.047 \times 0.621 \pm 0.065 \mu \mathrm{m})$. Large crystals were also comparatively smaller in Bti-H14 (0.911 $\pm 0.080 \times 0.792 \pm 0.082 \mu \mathrm{m})$ than in Bt63 $(1.008 \pm 0.162 \times$ $0.901 \pm 0.125 \mu \mathrm{m})$. These differences were also evident 
Table 4 PCR-amplification profiles for the cry, cyt and chi genes of eight native Bt strains significantly more bioactive that the Bti$\mathrm{H} 14$ reference strain against An. gambiae larvae

\begin{tabular}{|c|c|c|c|c|c|c|c|c|c|}
\hline \multirow[t]{2}{*}{ Strain/Accession No. ${ }^{a}$} & \multirow[t]{2}{*}{ Mean $L C_{50}(\mu \mathrm{g} / \mathrm{ml})(\text { range })^{b}$} & \multicolumn{8}{|c|}{ Positive cry, cyt, and chi genes } \\
\hline & & cry $4 A a$ & cry $4 B a$ & cry 10 & cry 11 & cyt1Aa & Cyt1Ab & cyt2Aa & chi \\
\hline Bti-H14 - KJ722438.1 & $13.33(11.2-15.9)$ & + & + & + & + & + & + & + & $\overline{\text { no }}$ \\
\hline Bt10 - KF150482.1 & $4.96(4.41-5.58)^{*}$ & + & + & + & + & + & + & + & no \\
\hline Bt42 - KC414685.1 & $5.90(5.2-6.8)^{*}$ & + & + & + & + & + & + & + & no \\
\hline Bt55 - KC527056.1 & $4.11(3.6-4.6)^{*}$ & + & + & + & + & + & + & + & + \\
\hline Bt57 - KC527056.1 & $7.40(6.5-8.25)^{*}$ & + & + & + & + & + & + & + & no \\
\hline$B+58$ & $5.73(5.06-6.5)^{*}$ & + & + & + & + & + & + & + & no \\
\hline Bt63 - KF971833.1 & $3.90(3.4-4.4)^{*}$ & no & + & + & + & + & no & + & no \\
\hline Bt67 - KC527056.1 & $6.90(5.9-8.2)^{*}$ & + & + & + & + & + & no & + & no \\
\hline Bt68 - KC527056.1 & $5.16(4.5-5.8)^{*}$ & + & + & + & + & + & + & + & no \\
\hline
\end{tabular}

Abbreviation: no indicates absence of PCR-amplification

*Asterisks indicate significantly greater bioactivity compared to $\mathrm{BtiH} 14$ (see Table 3)

${ }^{a} 16$ s RNA sequences accession number when applicable

${ }^{b}$ Mean and range of lethal concentrations $\left(\mathrm{LC}_{50}\right)$

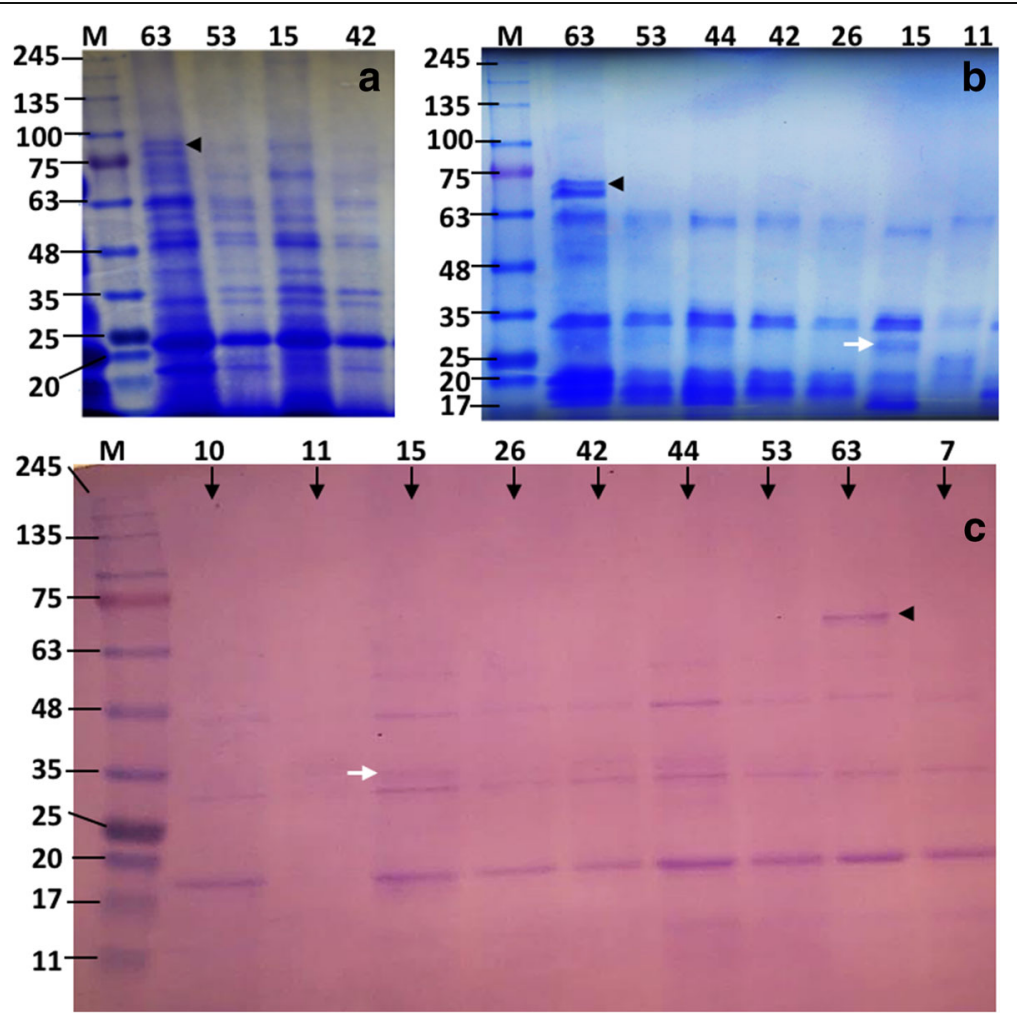

Fig. 3 SDS-PAGE profiles of whole parasporal crystals/spores mixtures. a Profiles after dissolution of protein crystals at alkaline $\mathrm{pH}$ (10.5-11). b Profiles following pH-neutralization. c Profiles after trypsin-treatment (silver stain). The reference Bt-H14 is labelled as Lane 15 and represented native $B t$ isolates labelled with their respective identification numbers (see Table 4). Lanes M: protein molecular mass markers (245 to $11 \mathrm{kDa}$ ). Across all three conditions, SDS-PAGE profiles were distinct between the highly bio-active native Bt-63 isolate and reference Bti-H14 with white and black arrows indicating bands present in one but not the other 


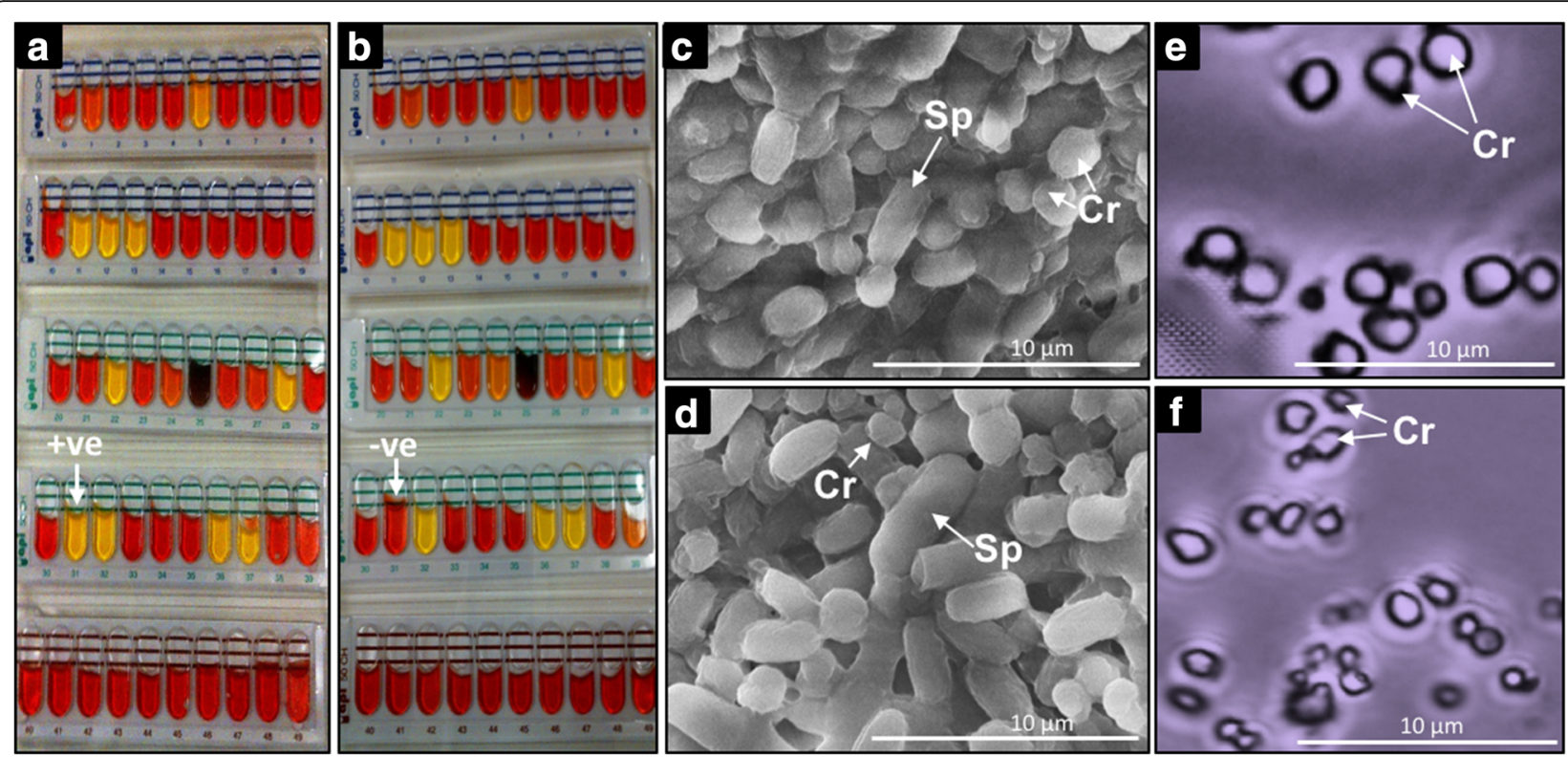

Fig. 4 Comparisons among the native Bt63 and the reference strain Bt-H14 through biochemical profiling, scanning electron micrography and phasecontrast microscopy. In a, biochemical profiling with the API 50CH system shows that the Bt63 isolate produces acid from sucrose (indicated by arrow), whereas in $\mathbf{b}$ Bti-H14 is negative (arrow); all other 49 biochemical reactions were similar. In $\mathbf{c}$ and $\mathbf{d}$, scanning electron micrograph $(\times 10,000)$ of Bt63 reveals its larger Cry crystals (Cr) and smaller spores (Sp) than those Bti-H14. In e and $\mathbf{f}$, the phase-contrast micrographs of sucrose gradient-separated Cry Crystals (Cr) from Bt63 appear, comparatively, larger than those of Bti-H14. Scale-bars: c, d, 1 um; e, f, $10 \mu \mathrm{m}$

from phase contrast microscopy of sucrose gradient crystal separation (Fig. 4e-f) [43].

\section{Discussion}

This study was carried out to create a collection of native $B t$ isolates that can potentially be used for developing biocontrol tools to help fight mosquito-borne diseases in Saudi Arabia. Under the assumption that sampling from different countries and region might uncover novel genetic diversity and toxic potential, $B t$ isolates were obtained from a variety of samples collected in different ecosystems in 16 regions of Saudi Arabia as they have extensive irrigation systems which creates an abundance of suitable mosquito breeding sites.

A total of $68 \mathrm{Bt}$ isolates were successfully isolated from 300 samples, which often contained more than one $B t$ isolates from the same sample. Most of these isolates (47.27\%) originated from soil samples collected from old urban regions, such as those from Al-Madinah and Makah. This contrasted with $B t$ negative samples, which came from less populated new city regions (mostly surrounded by vast desert land). About 35.3\% of recovered isolates were shown to have mosquito larvicidal activity and almost half of these came from Al-Madinah region, the oldest urban area in Saudi Arabia. This could be attributed to the extensive irrigation systems in that region which creates an abundance of suitable mosquito breeding sites. However, the presence of $B t$ is not strictly associated with the presence of mosquitoes and other insect in the soil, as past studies have found it in soils with little or no insect activity, and sometimes could not find it from soils with high insect activity [7]. Furthermore, and considering the fact that commercially available $B t i$ formulations do not last in the environment for long periods of time and that they have only been very rarely used in field evaluation in Saudi Arabia [42, 44, 45], the $68 B t$ isolates can be considered as part of the indigenous microflora of the areas explored.

As observed in other surveys $[4,25,40]$, a large amount of variation in crystal morphology was observed among the $68 \mathrm{Bt}$ field isolates. Furthermore, and in agreement with Martin et al. [40], the presence of anamorphous and/ or irregular crystals in 23 (32\%) of our isolates correlated with high mosquito larvicidal activity. In their study of the biochemical activity profiles of 3,639 Bt isolates from different countries, the same authors [40] suggested that urease producers were strongly associated with bipyramidal crystals toxic to Lepidoptera, whereas isolates with amorphous and/or irregular crystals tended to be toxic to Diptera, with general low metabolic activity, positive for acid production from starch and lecithinase and/or esculine hydrolysis [40].

In addition to their crystal shape, the 23 native larvicidal $B t$ strains showed similarities in their biochemical activity. Thus, all of these 23 strains were hemolytic for sheep RBCs, actively motile, positive for esculin hydrolysis, gelatinase, or phospho-lipase (lecithinase) activity. These strains, however, failed to produce acid from salicin and 
sucrose, except two strains (coded $B t-7$ and $B t-63$ ) which were sucrose positive. This is again in agreement with Martin et al. [40] who found that Bti-H14-like strains were positive for starch and lecithinase but negative for salicin and sucrose. Despite similarities in the crystal shape and biochemical profiles of larvicidal isolates, detailed testing of their larvicidal activity revealed much variation in their toxicity to the malaria mosquito An. gambiae. Thus, out of the $23 B t$ isolates, 8 displayed significantly higher toxicity against $A n$. gambiae than the reference Bti-H14 strain, whilst the remaining 15 isolates did not significantly differ from Bti-H14 in their larvicidal bioactivity, despite varying in their spore counts.

Amongst the $B t$ isolates with significantly enhanced larvicidal activity identified in this study, isolate $B t 63$ was the most toxic with a bioactivity against An. gambiae larvae 3.4-fold higher than H14. This isolate showed similar crystal shapes to those of Bti-H14, which included small spherical, triangular, merged ovoid double spherical and/or small double merged triangular crystals. However, SEMmorphometric measurements of the largest ovoid spherical crystals and of spores revealed remarkable differences between the two Bt strains, the former being larger in Bt63 and the later larger in Bti-H14.

In a survey conducted in Japan, Saitoh et al. [46] screened 1,449 local $B t$ isolates for larvicidal activity against the mosquito Anopheles stephensi and found the majority of their isolates (97.2\%) exhibited little or no larvicidal activity. In addition, the 2 most active Japanese isolates were 13-fold and 23-fold less active than the international reference BtiH14. Nowadays, several B. thuringiensis strains with good mosquitocidal activity have been isolated from various parts of the world such as Bt subsp. morrisoni PG-14, jegathesan, kyushuensis, medellin, darmstadiensis 73-E10-2 or Bt S2160. In all these isolates, a cytolytic toxin, generally 25 to $30 \mathrm{kDa}$, was also produced in addition to different Cry endotoxins; yet, except for strain PG-14, they were all less toxic to mosquitoes than Bti-H14.

In Latin America, Ibarra et al. [31] isolated 4 Bti-like strains with higher mosquitocidal toxicity than Bti-H14 despite sharing similar PCR profiles for the cry and $c y t$ gene-toxins. The authors pointed out that this higher bioactivity could be due to: (i) the cry and cyt genes detected by PCR may be encoding novel protein variants; (ii) the cry and cyt genes may be identical, but their expression levels may be different; or (iii) an undetected factor or protein may be responsible for their higher activity. The latter explanations may hold true for the native $B t 55$ strain described in this study, which had enhanced mosquitocidal activity, a similar cry and cyt gene profile as that of Bti-H14, but also possessed the Chi gene. The chitinase gene has been shown to elevate the mosquitocidal effect by perforating the peritrophic membrane, thereby increasing the accessibility of the
Cry and Cyt toxins to receptors on the epithelial membrane [7, 47]. Abdullah et al. [48] further experimentally demonstrated that transferring the chitinase gene from $B$. subtilis to a $B t$ strain improved its insecticidal bioactivity.

At the physiological and molecular levels, the highly toxic native Bt63, differed from Bti-H14 by having larger hemolytic and lecithinase activities and utilizing sucrose, which opens the possibility of bio-insecticide production using fermentation media such as locally-produced date molasses. In the $16 \mathrm{~S}$ rRNA neighbour-joining tree $B t 63$ was more closely related to Bti-H14 than to B. cereus, albeit not as close as some of the other isolates characterized in this study, which may also suggest a recent independent evolutionary trajectory. In addition, the SDSPAGE profiles obtained from different total protein extractions from crystal/spore mixture, were all strikingly different from those of Bti-H14 despite sharing many protein bands in Cry and Cyt regions [43]. In all cases, Bt63 showed an extra band of (68-72 to $99 \mathrm{kDa})$, possibly belonging to the naturally truncated Cry11, truncated fragment of a second cry $4 \mathrm{~B}$ gene or of cry60 genes [49].

PCR-detection profiles of $c r y$ and $c y t$ genes also revealed that Bt63 shared the cry $4 B a, c r y 10, c r y 11 A, c y t 1 A a$ and cyt2Aa bands with Bti-H14 but not those for the cry $4 A a$ and $c y t 1 A b$ gene. Our results also suggest that the amount of crystals/spore was higher in the native Bt63 than in BtiH14. The SEM observations of larger crystals and smaller spores combined with enhanced larvicidal activity (3.4fold) but lower overall spore count (6-fold) in Bt63 compared to Bti-H14 suggest that the loss of the large cry $4 A a$ could have been adaptively compensated by increased production and crystallization of cry and cyt toxins in the former strain. However, given the complexity and variety of transcriptional, post-transcriptional and posttranslational processes involved in the synthesis of $\delta$ endotoxins and sporulation process [2], this hypothesis remains to be further investigated. We believe that the native Bt63 strain could harbour the best combination of cry and cyt genes, resulting in elevated synergistic effects and, possibly, minimizing Cry competition for less specific receptors [18] or Cyt competitions for non-specific larval gut's receptors, which are key to synergetic oligomer pore-formation. In support for this hypothesis, Correa et al. [50] found that the combination of activated Cyt2Ba and Cry11A showed higher toxic activity than the two toxins activated solely, or a combination of Cry4Aa, Cry11A and Cyt2Ba used concomitantly, suggesting Cry4Aa competition and/or antagonistic effect. Therefore, in this study, the natural loss of Cry4Aa in the native Bt63 could increase the synergistic effect of Cry11Aa and Cyt1Aa and/or Cyt2Aa due to absence of Cry4Aa competition.

Overall, the data suggest that the native $B t-63$ strain is an environmental variant closely-related to $B t i-\mathrm{H} 14$, but which 
has lost the capacity to produce Cry4Aa and Cyt1Ab toxins, resulting in increased toxicity against dipteran larvae. Further studies are needed to test that hypothesis such as, for example, plasmid profile detection, plasmid and/or isolation, and/or cloning and transfer to an acrystalliferous $B t$ strain, and testing of mosquito toxicity of the resulting strain. Such studies might reveal the acquisition by Bt-63 of other $c r y$ and/or cyt genes that could help explain the distinct SDS-PAGE profiles obtained.

In agreement with the hypothesis that the loss of a Cry toxin can sometimes translate in increased larvicidal activity, Ibarra et al. [31] found that a native Bt strain (LBIT348) from Mexico which lacked Cry10 compared to a reference Bt-israelensis strain exhibited significantly higher mosquitocidal activity than the later strain. That is, despite the fact that the combination of Cry4, Cry10, Cry11 and Cyt toxins, is known to be very potent against mosquitoes [31]. Here, Bt63 contained the cry $4 B a$, cry10, cry11A, cyt1Aa and cyt2Aa genes, but lacked cry $4 A$. In Iran, Jouzani et al. [32] isolated $128 B t$ strains from different ecological regions of Iran with dipteranspecific toxicity and detected cry $4 B$ in $60 \%$ of isolates and cry $4 C$ or cry $4 D$ in $40 \%$ of isolates, whereas cry $4 A$ was not detected in any strains.

\section{Conclusions}

Various studies have emphasized various synergetic interactions between different combinations of Cry and Cyt proteins and how these can vary in their effectiveness against different mosquito taxa [51-54]. We believe that the discovery of the Bt-63 strain, native to the oldest city of Makkah in Saudi Arabia and isolated from its sewage water, may prove crucial for future bio-insecticide production against mosquito-vectors. This is due to its greatly enhanced mosquitocidal activity against An. gambiae, combined with possible economic and environmental advantages thanks to its, comparatively, larger Cry and Cyt toxin crystals, and its capacity to metabolize sucrose which opens the possibility to grow it on cheap or wastesbased fermentation media.

\section{Additional files}

Additional file 1: Table S1. GenBank accession numbers for the $16 \mathrm{~S}$ rRNA gene sequences of Bt strains and isolates and Gram-positive outgroup species of bacteria used in the neighbour-joining cluster analysis (DOCX $13 \mathrm{~kb}$ )

Additional file 2: Table S2. Universal (UN) and specific (sp) primers, amplicon size (bp), and annealing temperature $T_{a}$ used for PCR-profiling of the cry, cyt and chi genes. (DOCX $16 \mathrm{~kb}$ )

\section{Acknowledgements}

The authors would like to thank several anonymous referees for their helpful comments and suggestions.

\section{Funding}

This project was funded by the National Plan for Science, Technology and Innovation (MAARIFAH) King Abdulaziz City for Science and Technology, Kingdom of Saudi Arabia, Award number (11-MED-1848-02). The funder had no role in the design of the study and collection, analysis, and interpretation of data and in writing the manuscript.

\section{Availability of data and materials}

Sequence data are available on GenBank as described in Additional file 1: Table S1.

\section{Authors' contributions}

TAE designed and performed the experimental studies, for the physiological and molecular characterization of Bt strains. AMA performed field collection of environmental samples, carried out bioassay experiments and statistically analysed the experimental data. YAA provided the facilities, culture-media, basic chemical, solvent and reagents for performing Bt isolation, identification and mass propagation. FT provided the facilities and mosquitoes for bioassays, conducted the phylogenetic analyses, and finalized the manuscript. MSI helped in isolating, culturing and preparing Bt for bioassay experiments. AAM performed SDS-PAGE protein profiles of Bt strains. All authors helped in preparing the manuscript for publication and agreed with its final version. All authors read and approved the final manuscript.

\section{Competing interests}

The authors declare that they have no competing interests.

\section{Consent for publication}

Not applicable.

Ethics approval and consent to participate

Not applicable.

\section{Author details}

${ }^{1}$ Department of Clinical Laboratory Sciences, College of Applied Medical Sciences, King Saud University, Riyadh, Saudi Arabia. ${ }^{2}$ Department of Zoology, College of Science, King Saud University, Riyadh, Saudi Arabia. ${ }^{3}$ Centre for Applied Entomology and Parasitology, School of Life Sciences, Keele University, Staffordshire ST5 5BG, UK. ${ }^{4}$ Department of Food Science \& Nutrition, College of Food and Agricultural Sciences, King Saud University, Riyadh, Saudi Arabia.

Received: 30 May 2016 Accepted: 30 November 2016

Published online: 19 December 2016

\section{References}

1. Oestergaard J, Ehlers R, Martínez-Ramírez AC, Real MR. Binding of Cyt1Aa and Cry11Aa toxins of Bacillus thuringiensis serovar israelensis to brush border membrane vesicles of Tipula paludosa (Diptera: Nematocera) and subsequent pore formation. Appl Environ Microbiol. 2007;73:3623-9.

2. Ibrahim MA, Griko N, Junker M, Bulla LA. Bacillus thuringiensis: a genomics and proteomics perspective. Bioeng Bugs. 2010;1:31-50.

3. Aramideh S, Saferalizadeh MH, Pourmirza AA, Bari MR, Keshavarzi M, Mohseniazar M. Characterization and pathogenic evaluation of Bacillus thuringiensis isolates from West Azerbaijan province, Iran. Afr J Microbiol Res. 2010;4(12):1224-9.

4. Schünemann R, Knaak N, Fiuza LM. Mode of action and specificity of Bacillus thuringiensis toxins in the control of caterpillars and stink bugs in soybean culture. ISRN Microbiol. 2014;2014:1-12. http://dx.doi.org/10.1155/2014/135675.

5. Boonserm P, Davis P, Ellar DJ, Li J. Crystal structure of the mosquito-larvicidal toxin Cry4Ba and its biological implications. J Mol Biol. 2005;348:363-82.

6. Otieno-Ayayo ZN, Zaritsky A, Wirth MC, Manasherob R, Khasdan V, Cahan R, Ben-Dov E. Variations in the mosquito larvicidal activities of toxins from Bacillus thuringiensis ssp. israelensis. Environ Microbial. 2008;10:2191-9.

7. Argôlo-Filho RC, Loguercio LL. Bacillus thuringiensis is an environmental pathogen and host-specificity has developed as an adaptation to humangenerated ecological niches. Insects. 2014;5:62-91.

8. Bravo A, Sarabia S, Lopez L, Ontiveros H, Abarca C, Ortiz A, et al. Characterization of cry genes in a Mexican Bacillus thuringiensis strain collection. Appl Environ Microbiol. 1998;64(12):4965-72. 
9. Rampersad J, Ammons D. A Bacillus thuringiensis isolation method utilizing a novel stain, low selection and high throughput produced atypical results. BMC Microbiol. 2005;5:52-60.

10. Leoff C, Saile E, Sue D, Wilkins P, Quinn CP, Carlson RW, Kannenberg EL. Cell wall carbohydrate compositions of strains from the $B$. cereus group of species correlate with phylogenetic relatedness. J Bacteriol. 2008;190(1):112-21. doi:10. 1128/JB.01292-07.

11. Höfte H, Whiteley HR. Insecticidal crystal proteins of Bacillus thuringiensis. Microbiol Rev. 1989;53(2):242-55.

12. Crickmore N, Zeigler DR, Schnepf E, Van Rie J, Lereclus D, Baum J, et al. Bacillus thuringiensis toxin nomenclature. 2013. http://www.lifesci.sussex.ac. uk/home/Neil_Crickmore/Bt/intro.html.

13. Palma L, Muñoz D, Berry C, Murillo J, Caballero P. Bacillus thuringiensis toxins: An overview of their biocidal activity. Toxins. 2014;6:3296-325.

14. Bravo A, Gill SS, Soberon M. Mode of action of Bacillus thuringiensis Cry and Cyt toxins and their potential for insect control. Toxicon. 2007;49:423-35.

15. Tetreau G, Bayyareddy K, Jones CM, Stalinski R, Riaz MA, Paris M, et al. Larval midgut modifications associated with Bti resistance in the yellow fever mosquito using proteomic and transcriptomic approaches. BMC Genomics. 2012;13:248.

16. Tetreau G, Alessi M, Veyrenc S, Périgon S, David JP, Reynaud S, Després L. Fate of Bacillus thuringiensis subsp. israelensis in the field: Evidence for spore recycling and differential persistence of toxins in leaf litter. Appl Environ Microbiol. 2012;78:8362-7.

17. Berry C, O'Neil S, Ben-Dov E, Jones AF, Murphy L, Quail MA, et al. Complete sequence and organization of pBtoxis, the toxin-coding plasmid of Bacillus thuringiensis subsp. israelensis. Appl Environ Microbiol. 2002;68:5082-95.

18. Ben-Dov E. Bacillus thuringiensis subsp. israelensis and its dipteran-specific toxins. Toxins. 2014;6:1222-43.

19. Lee SB, Chen J, Aimanova KG, Gill SS. Aedes cadherin mediates the in vivo toxicity of the Cry11Aa toxin to Aedes aegypti. Invertebr Neurosci. 2015;68:140-7.

20. Deng C, Peng Q, Song F, Lereclus D. Regulation of Cry gene expression in Bacillus thuringiensis. Toxins. 2014;6:2194-209.

21. Abdullah MAF, Alzate O, Mohammad M, McNall RJ, Adang MJ, Dean DH. Introduction of Culex toxicity into Bacillus thuringiensis Cry4Ba by protein engineering. Appl Environ Microbiol. 2003;69:5343-53.

22. Wu D, Johnson JJ, Federici BA. Synergism of mosquitocidal toxicity between CytA and CrylVD proteins using inciusions produced from cloned genes of Bacillus thuringiensis. Mol Microbiol. 1994;13(6):965-72.

23. Tetraeu G, Stalinski R, David JP, Despres L. Monitoring resistance to Bacillus thuringiensis israelensis (Bti) in the field by performing bioassays with each Cry toxin superlatively. Mem Inst Oswaldo Cruz. 2013;108:894-900.

24. El-Kersh TA, Al-sheikh YA, Al-Akeel RA, Alsayed AA. Isolation and characterization of native Bacillus thuringiensis isolates from Saudi Arabia. Afr J Biotechnol. 2012;11(8):1924-38.

25. El-Kersh TA, Al-akeel RA, Al-sheikh YA, Alharbi SA. Isolation and distribution of mosquito-larvicidal Cry genes in Bacillus thuringiensis strains native to Saudi Arabia. Trop Biomed. 2014;31:616-32.

26. Baeshen R, Ekechukwu NE, Toure M, Paton D, Coulibaly M, Traoré SF, Tripet F. Differential effects of inbreeding and selection on male reproductive phenotype associated with the colonization and laboratory maintenance of Anopheles gambiae. Malar J. 2014;13, e19.

27. Jeanmougin F, Thompson JD, Gouy M, Higgins DG, Gibson TJ. Multiple sequence alignment with Clustal X. Trends Biochem Sci. 1998;23:403-5.

28. Gouy M, Guindon S, Gascuel O. SeaView version 4: a multiplatform graphical user interface for sequence alignment and phylogenetic tree building. Mol Biol Evol. 2010;27:221-4.

29. Dulmage HT, Boening OP, Rehnborg CS, Habsen GD. A proposed standardized bioassay for formulations of Bacillus thuringiensis based on the International unit. J Invertabr Pathol. 1971;18:240-5.

30. Bukhari A, Shakoori A. Isolation and molecular characterization of Cry4 harboring Bacillus thuringiensis isolates from Pakistan and mosquitocidal activity of their spores and total proteins. Pakistan J Zool. 2010;42(1):1-15.

31. Ibarra JE, del Rincon MC, Orduz S, Noriega D, Benintende G, Monnerat R, et al. A diversity of Bacillus thuringiensis strains from Latin America with insecticidal activity against different mosquito species. Appl Environ Microbiol. 2003;69:5269-74.

32. Jouzani G, Abad A, Seiffnejad A, Marzban R, Kariman K, Maleki B. Distribution and diversity of Dipteran specific Cry and Cyt genes in native Bacillus thuringiensis strains obtained from different ecosystems of Iran. J Ind Microbiol Biot. 2008:35:83-94.
33. Da Costa JRV, Rossi JR, Marucci SC, Alves EC, Volpe HXL, Ferraudo AF, et al. Toxic activity of Bacillus thuringiensis isolates to Aedes aegypti (L.) (Diptera: Culicidae) larvae. Neotrop Entomol. 2010;39(5):757-66.

34. Mahalakshmi A, Kabilan S, Poornima K, Rajaiah S. Distribution of Cry and Cyt genes among indigenous Bacillus thuringiensis isolates with mosquitocidal activity. Adv Microbiol. 2012;2:216-26.

35. WHO. Guidelines for laboratory and field testing of mosquito larvicides. 2005. (WHO/CDS/WHOPES/GCDPP/2005.13). http://www.who.int/whopes/ gcdpp/publications/en/index1.html.

36. Rey D, Cuany A, Pautou MP, Meyran JC. Differential sensitivity of mosquito texa to vegetable tannins. J Chem Ecol. 1999;25:537-48.

37. Abbott WS. A method of computing the effectiveness of an insecticide. J Econ Entomol. 1925;18:265-7.

38. Finney DN. Probit Analysis. 3rd ed. London: Cambridge University Press; 1971. p. 318.

39. Gobatto V, Giani SG, Camassola M, Dillon AJ, Specht A, Barros NM. Bacillus thuringiensis isolates entomopathogenic for Culex quinquefasciatus (Diptera: Culicidae) and Anticarsia gemmatalis (Lepidoptera: Noctuidae). Braz J Biol. 2010;70:1039-46.

40. Van der Auwera GA, Feldgarden M, Kolter R, Mahillon J. Whole-genome sequences of 94 environmental isolates of Bacillus cereus sensu lato. Genome Announc. 2013;1:e00380-13.

41. Martin PA, Gundersen-Rindal DE, Blackburn MB. Distribution of phenotypes among Bacillus thuringiensis strains. Syst Appl Microbiol. 2010;33:204-8.

42. Thomas WE, Ellar DJ. Bacillus thuringiensis var israelensis crystal $\delta$-endotoxin: effects on insect and mammalian cells in vitro and in vivo. J Cell Sci. 1983; 60:181-97.

43. Assaeedi A, Osman E, Abulreesh $\mathrm{H}$. The occurrence and insecticidal activity of Bacillus thuringiensis in the arid environments. Aust J Crop Sci. 2011;510:1185-90.

44. Al Otaibi SA. Toxicological studies on populations of cotton leaf worm during selection of recombinants in Bacillus thuringiensis as insecticidal agent. Int J Adv Biotec Res. 2012;3:752-67.

45. Al-Sarar AS, Al-Shahrani D, Bayoumi AE, Abobakr Y, Hussein HI. Laboratory and field evaluation of some chemical and biological larvicides against Culex spp. (Diptera: Culicidae) immature stages. Int J Agric Biol. 2011;13:115-9.

46. Saitoh H, Higuchi K, Mizuki E, Ohba M. Larvicidal toxicity of Japanese Bacillus thuringiensis against the mosquito Anopheles stephensi. Med Vet Entomol. 1998;12:98-102

47. Cai Y, Yan J, Hu X, Han B, Yuan Z. Improving the insecticidal activity against resistant Culex quinquefasciatus by expression of chitinase gene chiAC in Bacillus sphaericus. Appl Environ Microbiol. 2007;12:141-9.

48. Abdullah RR, Sukar NA, Ghanim NM. Improving the efficiency of Bacillus thuringiensis against insects of different feeding habits by plasmid transfer technique. Life Sci J. 2014;11:308-18.

49. Doggett NA, Stubben CJ, Chertkov O, Bruce DC, Detter JC, Johnson SL, Han CS. Complete genome sequence of Bacillus thuringiensis serovar israelensis strain HD-789. Genome Announc. 2013;1:e01023-13.

50. Corrêa RFT, Ardisson-Araújo DMP, Monnerat G, Ribeiro BM. Cytotoxicity analysis of three Bacillus thuringiensis subsp. israelensis $\delta$-endotoxins towards insect and mammalian cells. PLoS One. 2012;7:e46121.

51. Del Rinco'N-Castro MC, Barajas-Huerta J, Ibarra JE. Antagonism between Cry1Ac1 and Cyt1A1 toxins of Bacillus thuringiensis. Appl Environ Microbiol. 1999;65:2049-53.

52. Manasherob R, Itsko M, Sela-Baranes N, Ben-Dov E, Berry C, Cohen S, Zaritsky A. Cyt1Ca from Bacillus thuringiensis subsp. israelensis: production in Escherichia coli and comparison of its biological activities with those of other Cyt-like proteins. Microbiology. 2006;152:2651-9.

53. Promdonkoy B, Promdonkoy P, Panyim S. Co-expression of Bacillus thuringiensis Cry4Ba and Cyt2Aa2 in Escherichia coli revealed high synergism against Aedes aegypti and Culex quinquefasciatus larvae. FEMS Microbiol Lett. 2005:252:121-6.

54. Beltrão HBM, Silva-Filha MHL. Interaction of Bacillus thuringiensis serovar. israelensis Cry toxins with binding sites from Aedes aegypti (Diptera: Culicidae) larvae midgut. FEMS Microbiol Lett. 2006;266:163-9. 